\title{
Resolving Disputes among Islamic Countries within the Framework of Organization of Islamic Conference
}

\author{
Omid Andalib Firoozabadi \\ Department of Public Law, Faculty of Law, Arak Branch, Islamic Azad University, Arak, Iran
}

\author{
Doi:10.5901/mjss.2016.v7n4p682
}

\section{Abstract}

Organization of Islamic Conference is the only International governmental agency that has all Muslim countries as its members. Hence, this organization represents both the member states and Islam at the international level. The organization operates based on the charter approved by members come in 1972. It is a NGO and international mechanisms for Islamic countries to achieve Islamic solidarity. Original and divine sources of Islam encompass all Islamic principles and values. International relations inspired by the original Islamic sources has been developed and implemented among Muslim countries with the efforts of Muslim scholars and jurists. Some of the most recognized principles are equality, justice, respect, fulfillment of the covenant, cooperation, development, peace and security, respect for the right of self-determination, as well as preventing aggression, corruption, tyranny, and ultimately jihad. Statute of the Organization of Islamic Conference reflects and embodies the values and principles of Islam. The introduction to the Statute emphasizes on member states' commitment to preserve Islamic, spiritual, religious, social and economic values and principles; foreign targets of Muslim countries should be evidently the very embodiment of these principles. This research aims to examine the organization's capacity to enter legal disputes among member countries of this major political organization in the Muslim world.

Keywords: organization, Islam, capacity, rights, international organizations, international disputes

\section{Introduction}

One of the most controversial issues in international law is rules related to international claims, which includes the set of substantive rules on state responsibility for damages to foreigners. As a result of the globalization of economy, politics, culture and technology and increasing international exchanges, we witness more conflicts in various fields ranging from the interpretation and implementation of treaties and international conventions. Of course, increase and optimization political relations as well as massive increasing the level of massive political exchanges require various mechanisms such as independent, innovative, agile and efficient institutions to resolve disputes. Organization of Islamic Conference is one of the world's international organizations with 57 member countries in four continents (Fisher, 1985). With the onset of World War II, the age of pan-Islamic ideologies, in which the revival of Islamic creativity had been marked, ended and the Muslim world entered a new period of its political life. The facts of this period have left profound effects on the political opinions of Muslims. Accordingly, Islamist political forces in the Muslim world call for a united front of Islamic countries in the international system. The scope of OIC members contains countries that have a common thread or have common historical, geographical, cultural, and ... points. The common point in religious beliefs is the official center for aggregation. Islamic history is the source of inspiration for Muslim scholars and the motivation of political forces in the Islamic world. Indeed, based on a simple comparison between Muslims' controversial situation in modern era and their authority and glory during nearly 13 centuries, a common idea has emerged in Muslim societies that the reason for their current weakness is their division and dispersion. Hence, resorting to "Islamic unity" and growing the process of "Islamic consolidation" is main way to get rid of the current turmoil. This article aims primarily to find the conditions for resolving disputes among Islamic countries within the framework of organization of Islamic conference. Secondly, it reviews the political structure of Organization of Islamic Conference, capacity to resolve disputes in Islamic countries by the Organization of Islamic Conference, Organization of Islamic Conference within the framework of international treaties, and resolving disputes in Islamic countries.

\section{Research Background and Literature}

Organization is a group of people who are deliberately organized to achieve one or a set of common goals (Poursadegh, 2006). Capacity is also the ability and the obligation or the right and duty of both administrative and judicial authorities in 
dealing with disputes, complaints and issues especially as provided by law. Therefore, the legal authorities including administrative, judicial or quasi-judicial authorities are allowed to deal with the complaints and claims according to law (Goldberg, 1999). Moreover, in referral of the issue, they are obliged to consider and sentence; this ability and commitment is due to rule of law. Issues such as whether the subject is administrative or judicial, where is the place of investigation, and which authority should be identified with respect to the inherent or relative nature of capacity (Katouzian, 2005). In this regard, Organization of Islamic Conference has eight goals in its charter: (1) to enhance and consolidate the bonds of fraternity and solidarity among the Member States; (2) to support cooperation between Member States in economic, social, cultural, scientific and other basic the fields and consultations among the member states in international organizations; (3) efforts to eliminate racial discrimination and ending colonialism in all its forms; (4) to provide necessary measures to support international peace and security based on justice; (5) to support the struggle of the Palestinian people, who are presently under foreign occupation, and to empower them to attain their inalienable rights, including the right to self-determination, and to establish their sovereign state with Al-Quds Al-Sharif as its capital, while safeguarding its historic and Islamic character, and the holy places therein; (6) to support the struggle of all Muslim nations for the protection of the dignity, independence and national rights; (7) to create an atmosphere to enhance cooperation and understanding between Islamic countries and other countries; (8) decision-making in the organization, based on majority voting; but in practice, decisions are made by consensus during formal meetings (Bandeh Maqam, 2007). Here, it is necessary to point out some barriers to the integration of the Muslim Ummah. (1) Ethnic prejudice and blind imitation; (2) the emergence of ignorance, superstition and heresies; (3) mis-perceptions of the thoughts of other schools; (4) inadmissible and false accusations; (5) the emergence of authoritarian regimes; (6) neglecting policies of arrogance and turning to cosmetic differences; (7) magnification of disputes among Islamic groups; (8) the emergence of extremist groups and attracting people to their extreme views; (9) prevention of mutual recognition among followers of Islamic schools; (10) increasing sectarian violence and fratricide in Muslim lands (Hasanzadeh, 2000).

\section{Main Reasons for Differences among Islamic Governments}

Much of the disputes among Muslim nations results from the dependence of Islamic countries on the strong powers in the world. Many regimes of Islamic countries are according to the financing and foreign policy of strangers and few countries that are trying to show enough independence are under pressure. In addition, the Islamic countries are not economically developed and single-product economy enters a severe impact on the life of their economy. In terms of defense and military, the Islamic countries are indebted to foreigners. Enormous purchase of arms, signing defensive alliances with Western countries, the provision of foreign military bases, and holding joint exercises with them narrate the military dependence of the countries. Therefore, lack of self-sufficiency and dependence away Islamic states from the process of Islamic solidarity because dependence on the outside withdraws the opportunity to solidarity. This has led to formation of some new states with heterogeneous ethnic and religious combinations. Hence, the concepts of ethnicity, religion, majority, and minority stand out in these states; in this way, he necessary ground for the rise of internal conflicts is provided. Conflicts have gone outside quickly and adjacent states have involved. Today, some Islamic countries have deep border disputes. This reflects the victory of the colonial powers that has divided Islamic Ummah into more than fifty countries. Demarcation among these countries is set in a way that always causes tension, unrest, hit, and fights. International political poles intensify the atmosphere by various conspiracies to take its advantages consistently and increase hostilities (Bartlold, 2004).

\section{Legal Jurisdiction of Organization of Islamic Conference}

Organization' jurisdiction is a supplement to the jurisdiction of member states. It means that the Court has jurisdiction over crimes only when the competent countries are unable or unwilling to exercise their jurisdiction. According to Article 20 of the Statute and paragraph 7 of Article 14 of the International Covenant on Civil and Political Rights, previous prosecution of the offender or accused- either he has been convicted or acquitted- prevents a second prosecution in the Court (Double Jeopardy Principle). The Court has the capacity to refer or initiate a case is limited to the following: nationality principle, territorial principle, citizenship of offender or place of crime, referral by the Security Council, and accepting the declaration of acceptance of jurisdiction by non-member countries. The question is whether international organizations have international legal personality or not. This study assumes that international organizations have legal personality. The results of their international legal personality are (1) treaty-making power, (2) enjoying the privileges and immunities (3) providing diplomatic relations, (4) competence for international litigation. 


\section{Organization of Islamic Conference and International Disputes}

\subsection{Legal Reasons for OIC's entrance into international disputes}

Irritation and stresses of invasion to Iraq was the biggest challenge facing the Islamic world from the secular Egypt to the burning prayers of Quran reciters and imams in Mecca and Medina at the beginning of 2003. Among the religious leaders of the world, Christian world and the Pope John Paul II made the greatest effort to prevent attack to Iraq. Tibetan Buddhist leader, Dalai Lama, and Nobel Peace Prize laureate was silent mysteriously towards the incident. Remains of Christian saints such as Mother Teresa were shipped to Iraq to stop war and bloodshed in Iraq due to the consecration of the bodies. Nevertheless, reading from the Bible, US president, George Bush, start the war in full force on the deck of his warship in the Persian Gulf after the end of the Hajj and he recommended his soldiers to christening and called them martyrs of the right path. He called America as agent of human freedom from evil demons and he called his battle clearly a battle between right and wrong. After this surprising event for the whole world in general and Islamic world in particular, the political leaders of Islamic countries began to reform and remove some of their educational texts with incredible rapid and extreme confusion while centuries had passed for these teachings to be penetrated in the cultural context and beliefs of people of Islamic countries. Pakistan and Saudi Arabia that were the first suspects of growing terrorism held a contest for reforms; then, Egypt and Jordan join this contest. Meantime, since Egypt could not implement reforms as fast as Pakistan and Saudi Arabia, they managed to reduce the power of domestic opponents by arresting its leaders and members of the influential Muslim Brotherhood to pave the way for high-speed movement to reform inner and fanatic religious texts and religious beliefs (Cordesman, 2003). As the most experienced and qualified center of the Islamic world to issue fatwas in, Al Azhar repeatedly reacted to the various events over the past year and called for being a winner in this contest. National plan for changing textbooks (arising from Quranic verses and interpretations of prominent thinkers of Muslim world) and Elimination of all cases discussing the necessity of Islamic Jihad and struggle with heresy of atheism are the most controversial actions of Saudi government under repeated pressure from the US government after the events of September 11. In Indonesia and Malaysia, influential Islamic scholars were pioneer and shouted the the need for fundamental changes in Islamic beliefs repeatedly in speeches while the government had not started the changes. Muslims in Indian Subcontinent and Kashmir were the only groups whose bias did not allow Hindu extremists to speak of reforms. Suicide attacks were increased in Palestine and Lebanon in 2003 and young Muslims began to act because they were desperate of Muslim leaders' diplomatic practices. They shouted for their violated pride and identity by suicide attacks. In this regard, their zeal (which had been blamed repeatedly by Islamic leaders and authorities like Fadlallah and Mahathir Mohamad, sheikhs of Al-Azhar and even Pope John Paul II) was called a non-religious practice. However, the appearance of the Islamic countries was remarkable in 2003 so that this year can be known as a turning point in the history of religion (Bandeh Maqam, 2007). In his book "Own Philosophy," Muhammad Iqbal Lahoori predicts that Tehran will be the headquarters of the Muslims in the future. His prediction was fulfilled after the Islamic revolution in Iran led by Imam Khomeini and Iran became the mother of Muslim world. Due to unique situation in the region, having a rich, vast and endless source of energy, strong and attractive cultural and religious instruments, Iran has been able to become a center for organizing modern Islamic civilization.

\section{Remarkable Oil and Gas Reserves}

The strategic importance of Iran id evident with respect to importance of oil and gas resources in the development of global economy because Iran is one of the richest countries in oil and gas reserves. In addition to abundance of oil and gas in Iran, Iranian oil and gas are among best oils and gases in the word due to ease of extraction, low production costs, and high quality.

\section{Strategic Location}

Several neighbors surrounding Iran. Some of them are the cause of regional crises. Having been surrounded by the crises and the neighboring countries represents the geographical importance of Iran because each is trying to take advantage of Iran's geographical location for its own national interests. Besides, the United States adopted a hostile stance against Iran after the Islamic Revolution. The hostility is due to revolutionary slogans and stances such as neither East nor West, regional and international independent policy of the Islamic Republic (as denying the existence of Israel), threatening the West's economic interests (such as the possibility of preventing the export of cheap oil), etc. Despite the friendly relations between Iran and Russia, the bitter memory of its numerous wars against Iran should not be forgotten. 
This is important because the Russians continue the strategy of reaching the warm waters of the Persian Gulf and they know Iran as the shortest way to achieve it. Moreover, the Russians have staged a comprehensive economic competition with Iran in Central Asia and the Caucasus. Russia regards all independent republics as its own security privacy and prevents Iran from attending or peaceful ties in Central Asia and the Caucasus. Relation between Saudi Arabia and Iran has improved in recent years; but factors such as economic, political, and military dependence of Saudi Arabia on the United States and the claim of Muslim world leadership by Saudi Arabia have led the relations between the two countries to be subject of threats and challenges. Since separating Afghanistan from Iran on the basis of the Treaty of Paris in 1875 , borders and relations between the two countries have been fluctuated and unstable. Border insecurity and instability in the relations between the two countries were deepened with the establishment of communist rule in Afghanistan (1977) and the former Soviet Union invasion to the country (1979), and the beginning of the civil war (1992). Bilateral relations have been improved with the rise of Hamid Karzai. Past Ottoman and Turkey's today have been one of the most critical crises of Iran's neighbors. Now, the rule of secular thought in its educational and political systems, active membership in NATO, conclusion of military alliances with the United States and especially Israel, following Pan-Turkism ideas, widespread repression of opponent Kurds, and military intervention in northern Iraq are areas of conflict and the crisis in relations between the two countries (Results of Islamic Summit Conference in Rabat, 2005).

\subsection{Islamic Conference and Promotion of Human Rights in Member States}

At the present secular world claiming the separation of religion from politics, one confronts successive deadlocks, failures, and challenges of communities in all open and close policies of governments. More tragic, growing corruption and destruction of the human race through different branches of individual and social corruptions will certainly the idea of human rights. According to scholars and politicians in West and East, tendency and return to the divine religion is the only savior of humankind from destruction in this chaotic situation of the world (Junqua, 2010). It depends on the unity of Muslims in the path of the Prophet and Quran. It will be achieved in the practice and implementation of Islamic duties and laws in Muslim societies.

\subsection{Islamic International Court of Justice}

Muslim countries should not expect their leaders to bring justice for them since they are dependent on other countries. Muslim world and the Muslim Ummah would not succeed untill they kill heroes and fighters, burn the Muslims' houses, and know themselves the leaders of Islam. The formation of Islamic conference, which is one of the good intentions of great people who has gone, should follow the way of Prophet (pbuh) to be able to revive right of the oppressed people from the oppressors' hands. Dialogue among civilizations is an important way to stand and speak in different societies. Here, the idea of Islam can be uttered correctly. According to Islam, dignity, human values, prosperity, and ways to reach human prosperity are the most important issues that should be addressed in these communities and we can discuss it at the League of Nations. For this purpose, Western philosophers and theologians have to be invited to mull over the idea of Islam because it is believed that all divine prophets have come to remind their human dignity. It has been argued that Human beings have inherent dignity and they are created based on the mature wisdom of God; thus, it moves toward a sublime goal that will be reached by competition in the goodness and perfection.

\subsection{International Arbitration and Peaceful Settlement of Disputes}

Regulation of just and peaceful relations between states is the main purpose of international law and establishment of international organizations. Therefore, if a dispute rises among members of the international community, it is tried to settle the dispute in peaceful and fair ways, various approaches like international arbitration have been predicted in this regard.

An Islamic government may find subject of a dispute with governments that have diplomatic relations with them, or even the government does not have any relationship with it. In this case, Islam, which makes all its efforts to save the life of Muslims and human beings, should accept peaceful means at the first stage based on the its principles; for example, Muslims should accept international arbitration. Islamic legal system has predicted an institutional arbitration, which can be reflected in international arbitration. In Arbitration, there is no difference whether the parties are two individuals, two groups, or two states. Therefore, if two governments choose freely an individual, group or international organization as a judge in their disputes, the parties should be submitted to the person or authority after the verdict in Islam and the result of arbitration must be accepted (Mosa Zadeh, 2003). 


\subsection{Program of Organization of Islamic Countries Legal Department}

Development and adaptation of political, economic, social, and informing studies for:

1. To support and empower the Palestinian people to exercise their right to self-determination and establish their sovereign State with Al-Quds Al-Sharif as its capital.

2. Safeguarding its historic and Islamic character as well as the Holy places therein.

3. Prevention of Jewish immigration to Palestine and deal with any Zionist action.

4. Advancing and directing dissemination information activities in collaboration with institutions in Islamic countries.

5. Contribution to the effective role of the OIC in Quds and Palestine during the meetings in which the issue is raised.

6. To assist Muslim minorities and communities outside the Member States to preserve their dignity, cultural and religious identity.

7. Coordinating efforts to safeguard and protect the holy places, supporting the struggle of the Palestinian people and helping them regain their land rights, and supporting the struggle of all Muslim nations to maintain dignity, independence of their national rights.

8. Organization of the Islamic Conference follows up the coordination and direction of all countries o maintain the dignity, honor and interests of the Muslim world.

9. According to Article 5 and 6 , Headquarters of the Organization of the Islamic Conference will be established in Jeddah until the liberation of Quds.

10. Establishment of Israel Boycott Office and Asking countries of the world to observe Resolution 478 of the Security Council and and avoiding to relocate their Embassy to Quds.

11. Qods Committee.

The fourth meeting of foreign ministers in Jeddah in 1975 approved establishing Quds committee. Thirty-six meetings have been held; it is headed by Dakar (Senegal) and Islamic Republic of Iran is a member of this committee.

\section{Conclusion}

It can be concluded from the discussions on modern Muslim societies that the concept of Islamic unity has central role in the thoughts based on unity and cooperation of all Muslims around the world. This organization has some efforts such as preparation of a particular charter on human rights from an Islamic perspective and supporting some peace initiatives in the Middle East in line with new international order. Organizations' policies in response to international issues related to Islamic world match international values and norms. Interestingly, its charter has been influenced by the Charter of the United Nations. The examples of such correspondence are non-use of military force in resolving disputes, maintaining international peace and order, encouraging member states to cooperate and coordinate with non-member countries, and mutual respect for sovereignty and territorial integrity of all member countries. Article 2 of organizations' charter contains 7 goals and 5 principles that all emphasize on the cooperation of Islamic countries and support of Islamic countries to the Muslims in the defense of human dignity and their independence.

Organization's aims establish and maintain peaceful relations, expand and strengthen multilateral relations and precedents, and harmonize the policies of Member States in other international organizations. Paragraph 5 of the second part of Article 2 emphasizes on the need for peaceful relations between member states, international cooperation, and members' attention to the United Nations' Charter. This implies preventing the use of force. This paragraph also emphasizes on preventing threats or use of force (military force) against the territorial integrity, national unity or political independence of all member states. Insertion of the Palestinian issue in the text of the statute of the organization has changed the issue from a merely regional problem providing the concerns the Arab world to an important issue and concern to the Muslim world. In terms of relations with other countries, this statute (paragraph 4 and 7 of the first part of Article 2) emphasizes on peaceful foreign relations and international peace and security based on justice. Dakar Declaration states that the member countries should avoid using threat and military force against the territorial integrity and political independence of all states in their own relations or relations with non-member countries. Organizations' statute has not explicitly referred to establishment of a collective security system; but Article 2 points to some goals and principles that may refer indirectly to the collective security of member states. For instance, Paragraphs 3,4 and 6 of section $\mathrm{A}$ of Article 2 refer to combating racial discrimination, destroy colonialism in all its forms, applying the necessary tools to support international peace and security based on justice, and strengthening the fight against Muslim people to preserve the existence, independence, and territorial integrity of their countries. Of course, the organization stresses on 
formation of working group of governmental experts to strengthen the security of member states and it has carried out some measures to maintain public security such as expressing solidarity with the the people of Lebanon, Iran, Somalia and Sudan, condemning the actions in Afghanistan, the Arab-Israeli conflict, the war in Bosnia, and suspension of Afghanistan, and establishing Islamic Solidarity Fund and the Islamic Development Bank. Islam rejects the violent solutions to settle conflicts in Muslim societies and the organization makes all efforts to create a political-Islamic tradition in this regard. Peaceful settlement of disputes has been expressed frankly in Charter of the Organization of Islamic Conference. Paragraph 4 pf section two of Article 2 of the charter articulates that every dispute among member states should be resolved through peaceful means such as negotiation, mediation, conciliation, compromise, and arbitration; this is mentioned not only in the text of the charter but also as one of the principles of the charter. In addition, the first three meetings of Heads focus on provisions of the Charter for the peaceful settlement of disputes. In the fourth Summit in Morocco (Casablanca resolution), they insisted on peaceful settlement of disputes and the willingness of member states to establish regional reconciliation committee to resolve their differences by emphasizing geographical location of the members. In Tripoli Conference, Ministers of Foreign Affairs adopted a plan for establishment of a specialized permanent organ for resolving future disputes. New methods for the peaceful settlement of disputes among member states were adopted in the summit meeting in Saudi Arabia; it is called Islamic International Court of Justice.

Islamic International Court of Justice is a legal-juridical organ of the organization with three tasks: 1- juridical 2advisory, 3-political or arbitration.

It should be noted that about half of the member countries have refused to announce Islam as one of the main sources of law while the text of organization's charter introduces Islam as the main source of rulings; therefore, new problems have been risen. In addition, member states would prefer to resolve their disagreements through political rather than judicial measures. The organization has an effective role in solving 5 problems, namely Pakistan and Bangladesh, Iran and Iraq, Kuwait and Iraq, and Senegal and Mauritania wars as well as civil war in Afghanistan. Basically, the organization does not interfere in disputes related to regional organizations and involvement in the Iraqi- Kuwait (Arab Leagu) and Senegal-Mauritania (African Regional organizations) disputes have been exceptions.

Organization of the Islamic Conference has achieved limited success in any of its mediation efforts. Its achievements in the field of peaceful settlement of disputes among members and collective security have also been trivial. Organization's failure in peaceful settlement of disputes depends on several factors. One reason is simple and little standards for membership in this organization so that every developing country can apply for membership in this organization. Member of this organization have mostly underdevelopment and dependency in common. A major drawback of this organization is the fact that about $20 \%$ of the members are non-religious and secular regimes based on their constitutions. Muslims are a minority in some member states. For example, Uganda has $95 \%$ non-Muslim population. The presence of heterogeneous countries in various fields has kept the correlation and integration force of member countries at a low level. Another problem in the Organization of Islamic Conference arises from distribution and expansion of the member states' geographic area so that it reduces their political unity. In addition to the gap among countries, social gaps among the countries are significant so that some countries have good averages while some countries are much lower than the average. This heterogeneity can be seen in all aspects of member states, from political regimes to culture, race, and ethnicity. In general, other problems can be summarized in the following words:

1. The lack of territorial jurisdiction of organization;

2. The absence of a certain system of sanctions;

3. Lack of a specific voting system in summit conference, which brings the conclusion of weak, inconsistent, and unenforceable resolutions.

4. Membership problems including (1) only being Muslim is sufficient, (2) some countries do not participate, (3) some do not pay membership fees, (4) few countries have accepted the court's membership.

5. Given that Member States are normally among the countries of the South, Most are faced with the issue of human rights violations in Western terms. Although human right is a political need and demand, powerful countries are using it as a political tool against other countries.

Another issue in this regard is terrorism. Although member states have repeatedly blamed it, terrorism carried out by groups under the title of Islam caused disputes and pessimism against Islam and Islamic countries. There are some solutions regarding discussed problems and issues. In summary, establishing a system of economic-military sanctions against violators of the organization's laws, determining a certain voting system in the summit conference to avoid conflicting, weak and unenforceable resolutions, setting more precise membership requirements in order to prevent members from different countries with different conditions, creating unity and fundamental changes in the Secretariat in order to contribute to approval of more accurate and more effective provisions, careful monitoring or creating a committee for strict implementation of human rights from an Islamic perspective, and introduction of a mechanism for cooperation, 
consultation and negotiation with the Arab League and the Organization of African Unity about resolution of disputes among member states are solutions for solving problems.

\section{References}

Bandeh Maqam, Muhammad Mahdi. The etiology of the OIC formation and the role of Saudi Arabia, 2007.

Bartlold, Vasilii Valdimirovich. Mussulman culture. Translated by Abbas Behnezhad, Amir Kabir Publications, Tehran, first edition, 2004.

Cordesman, A. H. (2003). Saudi Arabia enters the twenty-first century: the political, foreign policy, economic, and energy dimensions (Vol. 2). Greenwood Publishing Group.

Fisher, P. (1985). Transnational Enterprises, in R. Bernhardt (ed.), Encyclopedia of Public International Law, Vol. 8 pp. 515-19

Goldberg, L. R. (1999). A broad-bandwidth, public domain, personality inventory measuring the lower-level facets of several five-factor models.Personality psychology in Europe, 7, 7-28.

Hasanzadeh, Mahmood. Idealism of Muslim community, Phoenix Publishing, Tehran, 2000.

Junqua, A. (2010). Destruction and Survival of the Written Word in Joseph Addison's Periodical Prose. XVII-XVIII. Revue de la société d'études anglo-américaines des XVIle et XVIIIe siècles, 2(1), 197-219.

Katouzian, Naser. Katouzian Glossary (Terms of law). Tehran University Press. 2005.

Mosa Zadeh, Reza. International Organizations. Mizan Publication, Tehran, Third edition, 2003.

Poursadegh, Ali. Organization and the public domain. Published by the Institute of Cultural Studies, 2006.

Results of Islamic Summit Conference in Rabat, 2005. 